\title{
The Face of Al-Quran on Islamic Education Curriculum in Indonesia
}

\author{
Heri Khoiruddin, Ade Nandang, Heris Herwaman and Hapid \\ Faculty of Tarbiyah and Teacher Training \\ State Islamic University of Sunan Gunung Djati Bandung \\ Bandung, Indonesia \\ herikhoiruddin@uinsgd.ac.id
}

\begin{abstract}
The success of Rasulullah in changing the behavior of Arab society, was influenced among others by the coming of the Koran. The verse that descended on Mecca was in accord with the needs of the people of Mecca at that time. The periodization of the coming of the Koran is the stage of teaching in Islamic education run by the Prophet. This periodization can also be used as a guide as to which teaching materials should be delivered at an early and the next stage. For this reason, this paper aims to determine the suitability between the periods of the coming of the Koran and the Islamic education curriculum. Efforts made to determine this suitability are by browsing the verses of the Koran, that are learned in the Institute of Islamic Education through the curriculum taught in class XI-XII Madrasah Aliyah, specialization in the field of interpretation religious studies and interpretation of tafsir. The results obtained from this search indicate that the surah descended during the Mecca period are dominates as the surah taught in class XI-XII, or about $56 \%$ for class XI and about $60 \%$ for class XII.
\end{abstract}

\section{Keywords-mecca; medina; curriculum}

\section{BACKGROUND}

The gradual coming of the Qur'an over a period of almost 23 years, can be understood as a teaching strategy undertaken by God for humans. Within that period, the coming of the Qur'an can be divided into two periods, namely the period of Mecca and Medina. The period of Mecca (about 610 AD) is the period of verses that descended on Mecca, while the period of Medina (about $622 \mathrm{AD}$ ) is the period of the descending verses in Medina. The period of Mecca amounted to 91 surahs, while the Medina period numbered 23 surah [1].

The two periods above can be divided into several periods of teaching the Qur'an. Shihab [2] divides the period of the coming of the Qur'an into three, namely: (1) the first 4-5 years period, related to the Prophet's education in shaping his personality, basic knowledge about the nature and actions of God, Islamiyah, and the general denial of the view of the life of the ignorant society; (2) the second year of 8-9 period, in relation to the principal obligation that must be exercised by the Muslims in accordance with the conditions at the time and the denial to annul the ignorance from various points of view; (3) the last 10 years, related to guidance to Muslims to the path of God, encouraging to strive for jihad in the way of Allah, and discipline Islamic morality in accordance with the conditions at that time.

In contrast to Quraish Shihab, in Taufik Adnan Amal's book, the periodization of the coming of the Qur'an is divided into four periods, namely the first Makkiyah period, the second Makkiyah period, the third Makkiyah period, and the Madaniyah period [3]. The transitional point for these four periods is the period of migration to Abyssinia (about $615 \mathrm{AD}$ ) for the first and second Makkiyah periods, at the return of the Prophet from Ta'if (about 620 AD) for the second and third Makkiyah periods, and the Hijrah (about September 622 AD ) for the third Makkiyah and Madaniyah periods. Except on the basis of division into four periods, the second period in the division of Quraish Shihab is the second and third period in Taufik Adnan Amal's book.

The study of the teaching period based on the descent of the Qur'an becomes interesting based on the suitability of the material to its target. Each verse that comes down has a specificity, either on the scope or the problems it faces. Generally the verses that descend on Mecca targeted the humanitarian matters territorially in Mecca, and the Qur'anic view for the issues is Comprehensive. The theme is how to build up the joints of the faith and equality of fellow human beings. While the passages that descend on Medina targeted the territorial humanitarian matters in Medina, and the Qur'anic view of the issues was partial. The theme was how to reorganize the structure of Medina society [4].

Islamic teaching, especially the teaching of the Qur'ann in the world of education has been widely studied, both nationally and globally, as written by Khan [5] in his dissertation, The Aplication of Quran and Hadith in The Teaching of Life Skills in Muslim Schools in South Africa, Nasir [6] which examines Madrasah Curriculum: Comparative Study of Madrasahs in Asia, Abong [7] which examines the Curriculum Constellation Education in Indonesia, Irham [8] who studied Islamic Education at Multicultural Schools, and Abdul [9] who studied Junior-Senior High School Based on Pesantren Boarding System.

Along with the change of curriculum in Indonesia, the teaching of Al- Quran continues to change. The curriculum change in Indonesia was so fast, from the 1975 curriculum to the 1984 curriculum, then changed into the 1994 curriculum, 
changed back into the 2000 curriculum, then became the 2004 curriculum, changed into the 2006 curriculum (KTSP), and last one, became the 2013 curriculum, in which, according to Rustam Abong, is very thick with the constellation of power. The impact of the curriculum change must have an impact on the teaching of the Quran in it [7].

The teachings of the Qur'an in Indonesia for the moment can be traced through the verses that are preached in schools, especially in Islamic Education Institutions such as Madrasah Ibtidaiyah, Madrasah Tsanawiyah, and Madrasah Aliyah. Regulation of the Minister of Religious Affairs of the Republic of Indonesia No. 000912 of 2013 on the curriculum of madrasah 2013, requires the Islamic Education Institute to hold Teaching Practice Lesson on the subject of Quran Hadith as much as 2 hours of lessons per week, since a student pursued the first grade of Madrasah Ibtidaiyah up to grade XII Madrasah Aliyah [10]. For the specialization of religious Sciences, is given to the students of Madrasah Aliyah with the obligatory subject matter of Quran Hadith as much as 2 hours of lessons per week for X-XII class plus the subjects of interpretation and tafsir as much as 2 hours of lesson for class $\mathrm{X}$ and 3 hours lesson for class XI-XII. For the specialization of the field of interpretation studied in class XI-XII and for the specialization of the field of interpretation is studied in class X. Under this provision, then the verses of al- Quran studied at the Institute of Islamic Education can be traced through the curriculum taught in class XI-XII Madrasah Aliyah specialization of religious sciences in the field of interpretation and interpretation of tafsir. The results of the search on the XIXII class curriculum will give us an idea of how the Qur'an faces the curriculum of Islamic education in Indonesia.

This paper is different from some of the above, including what was written by Khan or Nasir. This paper is related to the teaching material of the Qur'an that is taught in Madrasah, with the purpose is to know the verses used as a source of learning by students of class XI-XII based on the periodase of the coming of the Qur'an. With the knowledge of this periodization, the similarities and differences of teaching that God gave through the periodization of the coming of the Qur'an with the teachings of the Qur'an given to the curriculum of Islamic education in Indonesia will be figured out.

\section{AL-QURAN FOR CLASS XI}

The verses of The Quran that are taught to class XI are classified into nine themes, namely: (1) obedience to God and His Messengers; (2) to know the greatness and power of God; (3) gratitudes for God's blessings; (4) amar maruf nahi munkar; (5) halal and haram food; (6) simple life; (7) preserving nature; (8) patient in the face of various conditions; (9) has a tolerant and ethical attitude in the association. For class XI, the verses used as learning resources amount to 18 surah 64 verses.

The reference verses of obedience to Allah and His Messenger are Surah An-Nur (24): 54 and an-Nisa (4): 80. In surah An-Nur (24): 54 each person is required to obey God and obey the apostle, and if he turns away, then the Apostle's duty is only what is laid upon him. Whereas in surah an-Nisa (4): 80 it is affirmed that whoever obeys the Apostle means he has obeyed God, and whoever turns away then the Apostle is not a keeper. Both of these suras came down in Medina. Surah anNur is the 102nd surah and the surah an-Nisa is the 97th surah.

The reference verse of the greatness and power of God is the Surah An-Nahl (16): 65-70; Al-Baqarah (2): 164; An-Nahl (16): 72; Al-Isra (17): 12; and Al-Anbiya (21): 30. Surah AnNahl (16): 65-70 regarding the greatness of God about rain water, beverage from livestock, drink of fruits, and beverages from bees as medicine. Surah Al-Baqarah (2): 164 is concerning the creation of heaven and earth, day and night, rain, wind, and clouds. Surah An-Nahl (16): 72 is related to the creation of couples and the development of heredity through marriage. Surah Al-Isra (17): 12 is relating the creation of day to day and night to rest. Surah Al-Anbiya (21): 30 is regarding the earth and the sky that was originally united then separated. Of these four suras, three suras were revealed in Mecca, namely surah al-Isra, an-Nahl, and al-Anbiya. Surah al-Isra is the 50th Surah, the Surah an-Nahl is the 70th Surah, and Surah Al-Anbiya is the 73rd Surah. While a Surah is revealed in Medina, that is Sura Al-Baqarah which is 92th Surah.

The verse that is used as a reference to thank God for the blessings of Allah is the Surah Az-Zukhruf (43): 9-13 and AlAnkabut (29): 17. Surah Az-Zukhruf (43): 9-13 is related to God's blessings of earth as a place of residence and roads on earth for clues as well as rainfall down to a certain size. While in surah Al-Ankabut (29): 17 it is related to the need to give thanks to the Provision of sustenance and not to other than Him. Both these surahs came down in Mecca. Surah AzZukhruf is based on the chronology of the coming is the 63rd chapter and the surah al-Ankabut is the 85th chapter.

The reference verse of Amar Maruf Nahi Munkar is Surah Ali Imran (3): 104; Al-Maidah (5): 78-80; and ash-Shaf (61): 3. Surah Ali Imran (3): 104 is regarding the necessity to Amar Maruf Nahi Munkar. Surah Al-Maidah (5): 78-80 is related to the corruption for the people who help in Munkar. Surah ashShaf (61): 3 is related to the prohibition to say what not to do. These three Surahs came down in Medina. Surah Ali Imran is the 94th Surah, Surah ash-Shaf is the 109th Surah, and Sura Al-Maidah is Surah 112.

The reference verses of halal and unlawful food are surah Al-Baqarah (2): 172-173; Al-Maidah (5): 87-88; An-Nahl (16): 66, 68-69; Al-Baqarah (2): 219; and Al-Maidah (5): 90-91. Surah Al-Baqarah (2): 172-173 related to the necessity to eat good food and the carcass of dead carcasses, blood, pork, and what is slaughtered not by mentioning God's name. Surah AlMaidah (5): 87-88 with regard to the prohibition of overstepping food and drink, and having to eat halal and good food. Surah An-Nahl (16): 66, 68-69 is related to healthy drinks produced from bee stomach. Surah Al-Baqarah (2): 219 is related to the prohibition of drinking khamar and intoxicating. Surah Al-Maidah (5): 90-91 is related to the ban of drinking khamar. From these three chapters, one Surah descends in Mecca, which is the Surah a n-Nahl also the 70th Surah. Whereas the two Surahs are revealed in Medina, ie Sura al-Baqarah and al-Maidah. Surah al-Baqarah is the 92th Surah and the Surah al-Maidah is the 112th Surah.

The reference verse of simple living is the Surah AlQashash (28): 79-82; Al-Isra (17): 26-27, 29-30; and Al- 
Baqarah (2): 177. Surah Al-Qashash (28): 79-82 relates the story of Qarun who was given wealth but did not Shaw gratitude. Surah Al-Isra (17): 26-27, 29-30 regarding the prohibition of squandering wealth extravagantly, and too much or too miserly in using it. Surah Al-Baqarah (2): 177 regarding the necessity to share to others. Of these three chapters, two surahs were revealed in Mecca, namely surahs a -Qashash and al-Isra. Sura a 1-Qashash is the 49th surah and surah al-Isra is the 50th chapter. Whereas one surah is revealed in Medina, that is Surah al-Baqarah which is the 92 th Surah.

The reference verses of nature preservation are surah AlBaqarah (2): 267-268 and Al-Maarij (70): 19-25. Surah AlBaqarah (2): 267-268 is related to the necessity to do good. While surah Al-Maarij (70): 19-25 is related to people who set aside their property for good. From these two chapters, one surah descends in Mecca, the sura al-Maarij which is the 79th chapter, and another surah descended in Medina, the surah alBaqarah which is the 92th surah.

The verse referred to as patience in the face of various conditions is surah Al-Baqarah (2): 155, when in conditions of fear, hunger, lack of wealth, soul, and fruits, which is the 92th chapter and is the first who descended on Medina.

The reference verse of tolerance and social ethics is surah Al-Kafirun (109): 1-6; Jonah (10): 40-41; Al-Kahf (18): 29; Al-Hujurat (49): 10-13; Ali Imran (3): 103; and Al-Mujadilah (58): 11. Surah Al-Kafirun (109): 1-6 is related to tolerance and limitations when socializing with people of different religions. Surah Yunus (10): 40-41 regarding the existence of unbelievers then he will bear his own sin. Surah Al-Kahf (18): 29 regarding the place to be reserved for those who do not believe. Surah AlHujurat (49): 10-13 is related to the fraternity of fellow Muslims that must be maintained and the prohibition of prejudice which will be the cause of the split. Surah Ali Imran (3): 103 is concerning the need to unite and ban on divorce. Surah Al-Mujadilah (58): 11 regarding the virtue of sharing in the assembly of science. Of these six suras, three suras are revealed in Mecca, ie surah al-Kafirun, Yunus, and al-Kahf. Surah al-Kafirun is the 18th Surah, the Surah of Yunus is the 51st Surah, and Surah al-Kahf is the 69th Surah. While the other three Surahs are revealed in Madinah, ie Surah Ali Imran, al-Mujadilah, and al-Hujurat. Surah Ali Imran is the 94th Surah, sura al-Mujadilah is 105th Surah, and Surah Al-Hujurat is Surah 106..

More details, the 18 Surahs above can be seen in the following table I:

TABLE I. DETAILS OF THE 18 SURAHS FOR CLASS XI

\begin{tabular}{|l|l|l|}
\hline NO & \multicolumn{1}{|c|}{ SURAH } & \multicolumn{1}{c|}{ ORDER } \\
\hline 01. & al-Kafirun & 18 \\
\hline 02. & al-Qashash & 49 \\
\hline 03. & al-Isra & 50 \\
\hline 04. & Yunus & 51 \\
\hline 05. & az-Zukhruf & 63 \\
\hline 06. & al-Kahf & 69 \\
\hline 07. & an-Nahl & 70 \\
\hline 08. & al-Anbiya & 73 \\
\hline 09. & al-Maarij & 79 \\
\hline 10. & al-Ankabut & 85 \\
\hline 11. & al-Baqarah & 92 \\
\hline
\end{tabular}

\begin{tabular}{|l|l|l|}
\hline 12. & Ali Imran & 94 \\
\hline 13. & an-Nisa & 97 \\
\hline 14. & an-Nur & 102 \\
\hline 15. & al-Mujadilah & 105 \\
\hline 16. & al-Hujurat & 106 \\
\hline 17. & ash-Shaf & 109 \\
\hline 18. & al-Maidah & 112 \\
\hline
\end{tabular}

Based on the above details, the surah that descended on the Mecca period dominates as a Surah taught in class XI. Surahs that descended on the Mecca period amounted to 10 surahs or about $56 \%$. While the surah that descended on the period of Medina is amounted to 8 surah or about $44 \%$ of the total Surah used as a source of learning. For obedient behavior to Allah and His Apostle, the suras which are the source of learning are the two chapters of the Medina period. For the verse about the greatness and power of God, the suras which are the source of learning are the three chapters of the Meccan period and one surah of Medina period. For the behavior of gratitude for the favors of Allah, the suras used as the source of learning are two surahs of the Meccan period. For amar maruf nahi munkar, the surah used as the source of learning is the three chapters of Medina period. For halal and unlawful food, the surah used as a source of learning is a surah of the Meccan period and two surahs of Medina period. To live a simple life, the suras which are used as sources of learning are two surahs of the Meccan period and one of the Medinan surahs. For the preservation of nature, the surah used as a source of learning is a surah of the Meccan period and a surah of Medina period. For patience, the sura which is the source of learning is a surah of Medina period. For tolerance and ethics in association, the surah used as the source of learning are three chapters of the Meccan period and three surahs of Medina period.

More details, the surah details used as a learning resource for the above nine themes can be seen in the table II.

TABLE II. THE SURAH DETAILS USED AS A LEARNING RESOURCE FOR CLASS XI

\begin{tabular}{|l|l|l|l|l|}
\hline \multirow{2}{*}{ NO } & \multicolumn{1}{|c|}{ THEME } & $\begin{array}{c}\text { NUMER } \\
\text { OF } \\
\text { SURAH }\end{array}$ & COMING PERIOD \\
\cline { 4 - 5 } & & MECCA & MEDINA \\
\hline 01 & $\begin{array}{l}\text { Obeying Allah and His- } \\
\text { Apostle }\end{array}$ & 2 & 2 \\
\hline 02 & $\begin{array}{l}\text { Greatness and Power of } \\
\text { Allah }\end{array}$ & 4 & 3 & 1 \\
\hline 03 & $\begin{array}{l}\text { Thankful for the blessings } \\
\text { of Allah }\end{array}$ & 2 & 2 & \\
\hline 04 & amar maruf nahi munkar & 3 & & 3 \\
\hline 05 & Halaland Haram foods & 3 & 1 & 2 \\
\hline 06 & Simple Life & 3 & 2 & 1 \\
\hline 07 & Nature Conservation & 2 & 1 & 1 \\
\hline 08 & Patient & 1 & 3 & 3 \\
\hline 09 & $\begin{array}{l}\text { Tolerant and ethical in the } \\
\text { association }\end{array}$ & 6 & 3 & 3 \\
\hline
\end{tabular}

From the table above, the four themes taught in class XI refer only to a period of descent of the Qur'an , namely: obeying Allah and His Apostle, Amar Maruf Nahi Munkar, and patient, which only refers to the surahs revealed in Medina. Then grateful for the blessings of Allah which only refers to the surahs revealed in Mecca. Based on the above chart, the four themes above are taught to class XI not thoroughly based on 
the stage of al- Qur'an derivation or the stage of how the Qur'an is taught to the Prophet.

\section{AL-QURAN FOR CLASS XII}

The verses of the Quran taught to class XI I are classified into eight themes, namely: (1) having an honest and fair attitude; (2) development of sel, family and society; (3) the attitude of a Dai; (4) responsibility; (5) leadership spirit; (6) the personal work ethic of Muslims; (7) Concern in disputes solving, deliberation, and taarof; (8) attitude of enthusiasm in studying science. For class XII, verses used as learning resources are amounted to 20 surah 56 verses.

The reference verse of fairness and justice is Surah AlMaidah (5) : 8-10; An-Nahl (16) : 90-92; and An-Nisa (4): 105. Surah Al-Maidah (5) : $8-10$ is relating to the necessity of justice and the prohibition of making hatred a cause of injustice. SurahAn-Nahl (16) : 90-92 is regarding the need to be fair to relatives and prohibition of making oaths as a tool to deceive. Surah An-Nisa (4): 105 regards the necessity to be fair with what Allah has revealed. From these three chapters, one surah descended in Mecca, the Surah an-Nahl which is the 70th Surah, and the two other Surahs were descended in Medina, the Surah an-Nisa which is the 97th Surah and Surah al-Maidah which is the Surah 112.

The reference verses on the guidance of sel, family and society are surah An-Nisa (4): 9; Al-Baqarah (2): 44-45; AnNahl (16): 125; and Al-Baqarah (2): 177. Surah An-Nisa (4): 9 is concerning the need to coach and prepare a strong generation. Surah Al-Baqarah (2): $44-45$ is related to the necessity to conduct coaching that begins with self-guidance. Surah An-Nahl (16): 125 is related to the need to coach with wisdom, good lessons, discuss in the best way. Surah AlBaqarah (2): 177 is regarding the necessity to build self, family, and people closest. From these three surahs, one surah was descended in Mecca, the Surah an-Nahl which is the 70th Surah, and the two other Surahs were descended in Medina, the Surah al-Baqarah which is the 92th Surah and Surah an-Nisa which is the 97th Surah .

The reference verse about the attitude of a Dai is the Surah An-Nahl (16): 125; Asy-Syuara (26): 214-216; and Al-Hijr (15): 94-96. Surah An-Nahl (16): 125 is related to the necessity of preaching with wisdom, good lessons, and discussion in the best way. Surah Asy-Syuara (26): 214-216 is regarding the necessity of preaching by humbling themselves against those who are preached. Surah Al-Hijr (15): 94-96 is regarding the necessity of preaching openly. These three surahs came down in Mecca. Surah asy-Syuara is the 47th Surah, sura al-Hijr is the 54th Surah, and Surah an-Nahl is the 70th Surah.

The reference verse of responsibility is Surah At-Tahrim (66): 6; Thaha (20): 132; Al-Anam (6): 70; An-Nisa (4): 36; and Hud (11): 117-119. Surah At-Tahrim (66): 6 is concerning the necessity to keep oneself and family to avoid the fires of hell. SurahThaha (20): 132 is regarding the necessity to invite families to establish prayers and be patient. Surah Al-Anam (6): 70 regarding the prohibition of making religion as a joke and the necessity of keeping the family to avoid the fires of hell. Surah An-Nisa (4): 36 is regarding the necessity to do good to parents, family, relatives, and close neighbors. Surah
Hud (11): 117-119 relates to the obligation of every individual to keep his people from the destruction caused by iniquity. Of these five suras, three surahs were descended in Mecca, namely the surahs of Thaha, Hud, and al-Anam. Surah Thaha is the 45th Surah, Hud is the 52nd Surah, and Sura Al-Anam is the 55th Sura. The other two Surahs were descended in Madinah, ie Sura an-Nisa and at-Tahrim. Surah an-Nisa is the 97th The reference to the soul of leadership is the Surah An-Nisa (4): 58 -59 ; An-Nisa (4): 144; Al-Maidah (5) : 56-57; and At-Taubah (9): 71. Surah An-Nisa (4): 58-59 is regarding the necessity for the leader to establish a law fairly, and for those who are led to obey Allah, His Messenger, and Ulil Amri. Surah An-Nisa (4): 144 is related to the prohibition to make the unbelievers as guardians of the believers. Surah Al-Maidah (5) : 56-57 is related to the prohibition to make people who make religion as a joke as walli of the believers. Surah At-Taubah (9): 71 regarding the necessity to make believers a helper from one another. These three surahs came down in Medina. Surah anNisa is the 97th Sura, the Surah al-Maidah is the 112th Surah, and Surah At-Taubah is Sura 113. The reference to the Muslim work ethos is Surah Al-Jumuah (62): 9-11 and Al- Qashash (28) : 77. In Surah Al-Jumuah (62): 9-11 it is affirmed for believers to spread in advance to seek God's gift. While in AlQashash (28) : 77 is affirmed for believers to seek after life but not to forget the life of the world. From these two chapters, one surah descends in Mecca, the Sura of al-Qashash which is the 49th Surah, and one other Surah descended in Medina, the Surah al-Jumuah which is the 110th Surah.

Paragraph referenced on concern in solving dispute, deliberation, and taarof is Surah Ali Imran (3): 159; Al-Hujurat (49): 9; An-Nisa (4): 59; Al-Araf (7): 199; An-Nahl (16): 126; and Al-Hujurat (49): 13. Surah Ali Imran (3): 159 relates to the need to be gentle when it comes to settling disputes. Surah AlHujurat (49): 9 regarding the necessity to reconcile those who are at loggerheads. Surah An-Nisa (4): 59 regarding the obligation to obey Allah, His Messenger, and Ulil Amri, and if the dispute should return the matter to Allah and His Messenger. Surah Al-Araf (7): 199 relates to the forgiving nature that must be had when it comes to settling disputes. Surah An-Nahl (16): 126 is related should be able to give a worthy reply when disputing but it is advisable to be patient and forgive each other. Surah Al-Hujurat (49): 13 related to the creation of tribal and nations to know one another. Of these five suras, three two went down in Mecca, namely surah alAraf and an-Nahl. Surah al-Araf is the 39th chapter and the Surah an-Nahl is the 70th Surah. The other three Surahs descend in Madinah, ie Surah Ali Imran, an-Nisa and atHujurat. Surah Ali Imran is the 94th surah, sura an-Nisa is the 97th surah and sura al-Hujurat is the 106th surah.

The referenced verse about the spirit attitude in demanding science is surah Ali Imran (3): 190-191; Al-A ' raf (7): 179; AlIsra (17): 36; Ar-Rahman (55): 1-4, Al 'Alaq (96): 1-5; Jonah (10): 101; and Al-Baqarah (2): 164. Surah Ali Imran (3): 190191 is regarding the virtue of those who contemplate the creation of the heavens and the earth. Surah Al-A ' raf (7): 179 is regarding the necessity to use the heart, eyes, and ears to study God's creation. Surah Al-Isra (17): 36 regarding the prohibition to follow something we do not have knowledge about. Surah Ar-Rahman (55): 1-4 is concerning the necessity 
to study the Koran. Surah Al 'Alaq (96): 1-5 related to the necessity to read and study the various problems in the name of God. Surah Yunus (10): 101 concerning the necessity to pay attention to what is in the heavens and on earth to improve faith. Surah Al-Baqarah (2): 164 concerning the necessity to learn everything that happens on earth to improve faith. Of these seven suras, five suras were revealed in Mecca, ie surah al-Alaq, al-Araf, al-Isra , Yunus, and ar-Rahman. Surah alAlaq is the first surah, Surah Al-Araf is the 39th surah, Surah al-Isra is the 50th surah, Surah Yunus is sura 51, and Surah arRahman is surah surah 89. While two other t con in Madinah, namely the surah al-Baqarah and Ali Imran. Surah al-Baqarah is the 92th surah and the surah of Ali Imran is the 94th Surah. More details, details of the 20 surahs above can be seen in the following table III.

TABLE III. DETAILS OF THE 20 SURAHS FOR CLASS XII

\begin{tabular}{|l|l|l|}
\hline NO & \multicolumn{1}{|c|}{ SURAH } & \multicolumn{1}{c|}{ ORDER } \\
\hline 01. & al-Alaq & 1 \\
\hline 02. & al-Araf & 39 \\
\hline 03. & Thaha & 45 \\
\hline 04. & asy-Syuara & 47 \\
\hline 05. & al-Qashash & 49 \\
\hline 06. & al-Isra & 50 \\
\hline 07. & Yunus & 51 \\
\hline 08. & Hud & 52 \\
\hline 09. & al-Hijr & 54 \\
\hline 10. & al-Anam & 55 \\
\hline 11. & an-Nahl & 70 \\
\hline 12. & ar-Rahman & 89 \\
\hline 13. & al-Baqarah & 92 \\
\hline 14. & Ali Imran & 94 \\
\hline 15. & an-Nisa & 97 \\
\hline 16. & al-Hujurat & 106 \\
\hline 17. & at-Tahrim & 107 \\
\hline 18. & al-Jumuah & 110 \\
\hline 19. & al-Maidah & 112 \\
\hline 20. & at-Taubah & 113 \\
\hline
\end{tabular}

Based on the above details, the surah that descended on the period of Mecca are dominated as a surah taught in class XII. Surah that descended on the Mecca period amounted to 12 surah or about $60 \%$. While the surah Thar are descended on the Medina period amounted to 8 surah or about $40 \%$ of the total surah, used as a source of learning. For an honest and fair attitude, the sura which is used as a source of learning is a surah of the Meccan period and two surahs of Medina period. For self-help, family, and society, the suras that are used as a source of learning is a surah of the Meccan period and two surahs of Medina period. For attitudes as a Dai and dakwah duties, the surah used as the source of learning is the three chapters of the Meccan period. For the responsibilities, the surah used as the source of learning is the three surahs of the Meccan period and the two surahs of the Medina period. For leadership, the surah used as the source of learning is the three chapters of Medina period. For the work ethic, the surah used as a source of learning is a surah of the Meccan period and a surah of Medina period. To be concerned in the settlement of disputes, the source of the source of learning are the two surahs of the Meccan period and the three surahs of the Medina period. For the spirit in studying, the surah used as the source of learning is the five chapters of the Meccan period and two surahs of Medina period.

More details, the surah details used as a learning resource for the eight themes above can be seen in the tabel IV.

TABLE IV. THE SURAH DETAILS USED AS A LEARNING RESOURCE FOR CLASS XI

\begin{tabular}{|c|c|c|c|c|}
\hline \multirow[b]{2}{*}{ NO } & \multirow[b]{2}{*}{ THEME } & \multirow{2}{*}{$\begin{array}{c}\text { NUMBER } \\
\text { OF } \\
\text { SURAH }\end{array}$} & \multicolumn{2}{|c|}{ PERIODE TURUN } \\
\hline & & & MECCA & MEDIAN \\
\hline 01 & Honest and fair attitude & 3 & 1 & 2 \\
\hline 02 & $\begin{array}{l}\text { Self-development, } \\
\text { family, and community }\end{array}$ & 3 & 1 & 2 \\
\hline 03 & Dai and Dakwah & 3 & 3 & \\
\hline 04 & Responsibility & 5 & 3 & 2 \\
\hline 05 & LEadership & 3 & & 3 \\
\hline 06 & Work ethics & 2 & 1 & 1 \\
\hline 07 & $\begin{array}{l}\text { Concerned in giving } \\
\text { adjustment in a dispute }\end{array}$ & 5 & 2 & 3 \\
\hline 08 & Spirit in studying & 7 & 5 & 2 \\
\hline 09 & Honest and fair attitude & 3 & 1 & 2 \\
\hline
\end{tabular}

From the table above, the two themes taught in class XII refer only to a period of descent of the Qur'an, namely: dai and dakwah referring only to the surahs that were revealed in Medina. Then the leadership refers only to the surahs revealed in Mecca. Based on the above chart, the two themes above are taught to class XII not thoroughly based on the stage of alQur'an derivation or the stage of how the Qur'an is taught to the Messenger of Allah.

\section{CONCLUSION}

The Islamic Education curriculum, mainly taught in Madrasah Aliyah, specializes in religious studies in the field of interpretation and interpretation of Qur'an-dominated verses, or about $56 \%$ for class XI and about $60 \%$ for class XII. Although dominated verses are revealed in Mecca, some suras or verses in each class refer only to the criteria of certain Surahs. The four themes taught in class XI refer only to a period of the decline of the Qur'an, namely: obeying Allah and His Apostle, Amar Maruf Nahi Munkar, and patient, which only refers to the surahs revealed in Medina. Then grateful for the blessings of Allah which only refers to the surahs revealed in Mecca. The two themes taught in class XII refer only to a period of descent of theQur'an, namely: dai and dakwah which refers only to the surahs revealed in Medina. Then the leadership refers only to the surahs revealed in Mecca. Based on the above findings, what is taught to the Madrasah Aliyah class is mainly the field of interpretation and the science of exegesis, not thoroughly based on the stages of the deriving of the Qur'an or the stage of how the Koran is taught to the Prophet. This criterion asserts that the material of tafsir and the science of tafsir is taught is an almost balanced material between makkiyah and madaniyah, with a relatively diverse material in its sub-discussion between the theme of the formation of faith and equality, with how the structure of society is re-organized in the direction appropriate to the spirit of Al-Quran. 


\section{REFERENCES}

[1] Shihab, M. Quraish dkk. Sejarah dan Ulum al-Quran. Jakarta: Pustaka Firdaus, 2001.

[2] Shihab. M. Quraish. Membumikan Al-Quran. Bandung: Mizan, 1998.

[3] Amal, Taufik Adnan. Rekonstruksi Sejarah Al-Quran. Jakarta: Pustaka Alvabet, 2005.

[4] Khoiruddin, Heri. Kondisi Historis dalam Tafsir. Bandung: Fajar Media, 2013.

[5] Khan, Sadia. The Aplication of Quran and Hadith in The Teaching of Life Skills in Muslim Schools in South Africa. Disertasi di University of South Africa, November 2009.
[6] Nasir, Muhammad. Kurikulum Madrasah: Studi Perbandingan Madrasah di Asia. Nadwa, Vol. 9, No. 2, Oktober 2015, h. 145-166.

[7] Abong, Rustam. Konstelasi Kurikulum Pendidikan di Indonesia. AtTurats, Vol. 9, No. 2, Desember 2015, h. 37-47.

[8] Irham. Islamic Education at Multicultural Schools. JPI, Vol. 3, No. 2, Desember 2017, h. 141-154.

[9] Abdul Rohman. Junior-Senior High School Based on Pesantren Boarding System. JPI, Vol. 1, No. 1, Juni 2014, h. 123-144.

[10] Peraturan Menteri Agama Republik Indonesia Nomor 000912 tahun 2013 tentang kurikulum madrasah 2013 mata pelajaran Pendidikan Agama Islam dan Bahasa Arab. 